\title{
ANALISIS SWOT PADA PT HM SAMPOERNA (STRATEGI PERUBAHAN BISNIS)
}

\author{
Mahrawati \\ mahrawati@gmail.com
}

STIE Palangka Raya

\section{ABSTRACT}

The research method used in this research is descriptive method with casestudy research type. The research data collection technique is survey which was carried through interviews and questionnaires with the company director and general service manager of the sales department. The collection of data obtained was analyzed using SWOT analysis. For in order to make an accurate strategy for a company to run, it is necessary to begin with reviewing the company's strengths, weaknesses, opportunities, and also threats for the company.

From the SWOT analysis undertaken, it was figured that the IFAS value is 2,64584 and the EFAS value is 2,32827. Moreover, the IE matrix showed that the company's position is in the concentration strategy through horizontal integration or stability. This is a state where the company is experiencing a period of growth. These results inferred that the fittest strategy the company should implement is a growth strategy through horizontal integration. It is an activity to expand the company by building market, stores, and outlet sales in as many cities as possible in Indonesia, and also to improve the products through product innovations. The result of SWOT diagram also showed that the company carries out aggressive strategy or at quadrant 1 that possesses positive value.

From the research results, it can be concluded that the company should implement SO (Strengths-Opportunities) strategy for the company to maintain the ability to survive in the business competition.

Keywords: Analysis SWOT, Business strategy 


\section{PENDAHULUAN}

Perusahaan sekarang harus mampu untuk mengikuti perubahan yang terjadi baik di dalam maupun di luar perusahaan. Tentunya untuk mengikuti perubahanperubahan yang terjadi tersebut sangatlah tidak mudah.

Perusahaan yang cenderung berpikiran tradisional dan tidak mengharapkan adanya perubahan, tentunya akan menemui banyak kesulitan dalam menghadapi operasinya.

Setiap perusahaan tentunya memiliki strategi masing-masing dalam berbisnis. Permasalahannya adalah tepatkah strategi itu dipergunakan oleh perusahaan tersebut. Karena bila ternyata strategi yang diterapkan oleh perusahaan tersebut tidak sesuai dengan keadaannya, maka strategi tersebut akan mengakibatkan kegagalan bagi perusahaan tersebut.

Agar lebih mengerti dengan jelas mengenai strategi-strategi berbisnis suatu perusahaan maka penulis melakukan studi penelitian terhadap PT HM Sampoerna suatu perusahaan yang begerak dalam bidang usaha produksi Rokok. Perusahaan ini terus menerus melakukan perluasan usahanya dengan mendirikan pabrik baru dan lokasi pemasaran hampir seluruh wilayah Indonesia, mengingat semakin ketatnya persaingan di dalam industri rokok.

Strategi yang akan dibahas adalah tentang perkembangan daripada perusahaan itu sendiri dan keluaran yang dihasilkan. Hal ini tergantung tentunya pada faktorfaktor internal dan eksternal perusahaan. Faktor internal perusahaan adalah kekuatan dan kelemahan perusahaan, sedangkan faktor eksternal perusahaan adalah peluang dan ancaman yang akan dihadapi oleh perusahaan.

Penulisan ini didasarkan pada hasil penelitian yang dilakukan untuk mengenali, menganalisis, dan memahami implikasi dari penerapan suatu strategi perubahan bisnis tertentu. PT HM Sampoerna adalah perusahaan yang melakukan 
produksi dan penjualan produk-produk rokok, penelitian yang dilakukan pada perusahaan ini akan menghasilkan data yang akan diolah sehingga menghasilkan informasi yang bermanfaat.

Tujuan penelitian ini adalah : (1) Untuk menganalisis aspek internal dan eksternal PT HM Sampoerna (2) Untuk mengetahui kekuatan, kelemahan, peluang serta ancaman yang dihadapi PT HM Sampoerna dalam menjalankan strateginya (3) Dapat mengetahui strategi yang dapat dijalankan oleh PT HM Sampoerna dalam meningkatkan penjualannya dengan menganalisa SWOT perusahaan.

\section{TINJAUAN PUSTAKA}

\section{Pengertian Dan Konsep Strategi}

Menurut Stoner, Freeman, dan Gilbert. Jr (2001), konsep strategi dapat didefinisikan berdasarkan dua perspektif yang berbeda yaitu : (1) dari perspektif apa suatu organisasi ingin dilakukan (intends to do), dan (2) dari perspektif apa yang organisasi akhirnya lakukan (eventually does).

Berdasarkan perspektif yang pertama, strategi dapat didefinisikan sebagai

program untuk menentukan dan mencapai tujuan organisasi dan mengimplementasikan misinya. Makna yang terkandung dari strategi ini adalah bahwa para manajer memainkan peranan penting yang aktif, sadar dan rasional dalam merumuskan strategi organisasi. Dalam lingkungan yang turbulen dan selalu mengalami perubahan, pandangan ini lebih banyak diterapkan.

Sedangkan berdasarkan perspektif kedua, strategi didefinisikan sebagai pola tanggapan atau respon organisasi terhadap lingkungannya sepanjang waktu. Pada definisi ini, setiap organisasi pasti memiliki strategi, meskipun strategi tersebut tidak pernah dirumuskan secara eksplisit. Pandangan ini diterapkan bagi para manajer yang bersifat reaktif, yaitu hanya menanggapi dan menyesuaikan diri terhadap lingkungan secara pasif manakala dibutuhkan. 
Strategi secara eksplisit merupakan kunci keberhasilan dalam menghadapi perubahan lingkungan bisnis. Strategi memberikan kesatuan arah bagi semua anggota organisasi. Bila konsep strategi tidak jelas, maka keputusan yang diambil akan bersifat subyektif atau berdasarkan intuisi belaka dan mengabaikan keputusan yang lain.

Strategi merupakan cara untuk mencapai sasaran jangka panjang. Strategi yang digunakan dalam menjalankan kegiatan usaha dapat termasuk perluasan geografis, diversifikasi, akuisisi, pengembangan produk, penetrasi pasar, pengurangan, divestasi, likuidasi, dan usaha patungan. Sasaran dapat ditentukan sebagai hasil yang spesifik yang ingin dicapai sebuah organisasi dengan melakukan misi dasarnya. Jangka panjang berarti lebih dari satu tahun. Sasaran perlu untuk keberhasilan organisasi karena menyatakan arah, membantu dalam evaluasi, menciptakan sinergi, mengungkapkan prioritas, memfokuskan koordinasi, dan menyediakan dasar untuk perencanaan, pengorganisasian, memotivasi, dan mengendalikan aktivitas secara efektif. Sasaran harus menantang, dapat diukur, konsisten, pantas, dan jelas.

\section{Perumusan Strategi Bisnis}

Analisis faktor internal dan eksternal merupakan faktor yang sangat penting dalam merumuskan strategi bisnis perusahaan. Setiap perusahaan dapat mempunyai tujuan yang sama, akan tetapi strategi yang digunakan mungkin berbeda disesuaikan dengan kemampuan masing-masing (kekuatan dan kelemahan) serta peluang dan ancaman dari lingkungan yang dihadapi.

Hariadi, Bambang (2003) berpendapat bahwa ada tiga langkah utama yang dilakukan perusahaan dalam perumusan strategi adalah : (a) Mengembangkan visi dan misi. Visi manajemen merupakan suatu perspektif gambaran besar yang diinginkan tentang siapa kita ini (who we are), apa yang kita kerjakan (what we do) dan kemana kita akan pergi (where we headed) (b) Penetapan tujuan, Penetapan tujuan merupakan komitmen manajemen untuk mendapatkan hasil tertentu dalam waktu tertentu. 
Tujuan harus mengungkapkan tentang seberapa jauh kinerja yang ingin dicapai, kinerja macam apa dan kapan. Penetapan tujuan harus menetapkan apa yang ingin dicapai, kapan, dan siapa yang bertanggung jawab (c) Menyusun strategi, Setiap organisasi butuh sejumlah strategi untuk membimbing mencapai tujuan atau target tertentu dan bagaimana menjalani misi organisasi dengan sukses. Strategi untuk perusahaan secara keseluruhan, untuk tiap unit bisnis dan untuk tiap fungsi dalam organisasi. Tidak ada satu strategi yang berlaku untuk segala situasi.

\section{Strategi Bersaing}

Suatu perusahaan dikatakan mempunyai keunggulan bersaing bilamana memiliki sesuatu yang lebih atas pesaingnya dalam menarik konsumen dan mempertahankan diri atas kekuatan persaingan yang mencoba menekan perusahaan. Startegi bersaing perusahaan merupakan langkah-langkah strategis yang terencana maupun yang tidak terencana untuk dapat memiliki keunggulan bersaing sehingga dapat menarik perhatian dari konsumen.

Keunggulan bersaing dalam pasar akan memudahkan perusahaan untuk meraih keuntungan lebih besar daripada pesaing dan memberikan kesempatan hidup lebih lama dalam persaingan. Menurut Michael E. Porter dalam Hariadi, Bambang (2003) pola umum peta persaingan dalam pasar biasanya melibatkan lima kekuatan yang masing-masing saling menekan untuk memperoleh keuntungan yang maksimal.

Menurut Tunggal (2004) bahwa kekuatan-kekuatan bersaing yang terbesar menentukan kemampulabaan dari suatu industri, dengan demikian merupakan kepentingan yang paling besar dalam formulasi strategi. Setiap industri mempunyai struktur yang mendasar atau sekumpulan karakteristik ekonomi teknis dasar yang menimbulkan kekuatan bersaing tersebut. Beberapa karakteristik adalah krtikal terhadap kekuatan dari setiap kekuatan bersaing. 


\section{METODE PENELITIAN}

Dalam melakukan penelitian ini digunakan metode deskriptif adalah penelitian yang dilakukan untuk mengetahui nilai variabel mandiri atau lebih (independen) tanpa membuat perbandingan, atau menghubungkan dengan variabel yang lain. Dalam jenisnya penelitian ini menggunakan studi kasus.

Instrumen pengukuran yang digunakan adalah untuk mengukur faktor internal, yaitu kekuatan dan kelemahan perusahaan, serta faktor eksternal, yaitu peluang dan ancaman dalam bentuk kuisioner.

Adapun angka untuk pemberian bobot baik untuk faktor internal maupun faktor ekternal adalah sebagai berikut (1) Pengaruhnya kecil (2) Pengaruhnya sedang (3) Pengaruhnya paling besar

Pembagian nilai rating pada faktor internal adalah (1) Kelemahan utama (2) Kelemahan kecil (3) Kekuatan kecil (4) Kekuatan utama. Sedangkan pemberian nilai rating pada faktor eksternal adalah (1) Ancaman utama (2) Ancaman kecil (3) Peluang Kecil (4) Peluang utama.

Analisis ini dilakukan untuk mengidentifikasi kekuatan (Strengths), kelemahan (Weakness) dalam lingkungan internal perusahaan, dan peluang (Opportunities) serta ancaman (Threats) lingkungan eksternal perusahaan. Analisis kekuatan dan kelemahan yang ada di lingkungan internal terutama ditujukan terhadap faktor keberhasilan kunci (Key Success Factor). Jadi dengan analisis ini diharapkan akan diperoleh cara untuk mengembangkan dan memanfaatkan kekuatan serta penopang atau mengurangi kelemahan dengan maksud untuk memanfaatkan peluang dan mengurangi ancaman.

Teknik analisis data menggunakan statistik deskriptif. Statistik deskriptif adalah statistik yang digunakan untuk menganalisa data dengan cara mendeskripsikan atau menggambarkan data yang telah terkumpul sebagaimana adanya tanpa bermaksud membuat kesimpulan yang berlaku untuk umum atau generalisasi. Statistik deskriptif 
juga melakukan prediksi dengan analisis regresi, dan membuat perbandingan dengan membandingkan rata-rata data sampel atau populasi.

\section{HASIL PENELITIAN}

Mengidentifikasikan lingkungan internal meliputi kekuatan dan kelemahan, dan lingkungan eksternal yang meliputi peluang dan ancaman, maka telah dilakukan wawancara langsung dengan pihak-pihak yang terkait dengan penelitian ini.

Tujuan dari pembagian kuesioner ini adalah untuk mendapatkan berbagai rincian mengenai faktor internal yang terdiri dari kekuatan dan kelemahan perusahaan dan faktor eksternal yang meliputi peluang dan ancaman bagi perusahaan. Jawaban sebagai berikut :

\section{Rekapitulasi Faktor Kekuatan Internal}

Tabel 1. Rekapitulasi Faktor Kekuatan Internal

\begin{tabular}{|c|l|}
\hline No & \multicolumn{1}{c|}{ Faktor kekuatan perusahaan } \\
\hline 1 & Produk yang memiliki kualitas yang baik \\
\hline 2 & Harga produk yang relatif stabil \\
\hline 3 & Adanya layanan purna jual \\
\hline 4 & Lokasi perusahaan yang strategis \\
\hline 5 & Adanya brand image yang baik \\
\hline
\end{tabular}

Sumber : Hasil Kuesioner PT HM Sampoerna(2018)

\section{Rekapitulasi Faktor Kelemahan Internal}

\section{Tabel 2. Rekapitulasi Faktor Kelemahan Internal}

\begin{tabular}{|c|l|}
\hline No & \multicolumn{1}{c|}{ Faktor Kelemahan Perusahaan } \\
\hline 1 & Model Kurang Mengikuti Trend Pasar \\
\hline 2 & Kurangnya Disiplin Karyawan \\
\hline 3 & Keterlambatan Pengiriman Barang Ke Luar kota \\
\hline 4 & Pembagian Tugas Kerja Yang Tidak Teratur \\
\hline 5 & Kerusakan Barang Pada Saat Pengiriman \\
\hline
\end{tabular}

Sumber : Hasil Kuesioner PT HM Sampoerna (2018) 


\section{Rekapitulasi Faktor Peluang Eksternal}

Tabel 3. Rekapitulasi Faktor Peluang Eksternal

\begin{tabular}{|c|l|}
\hline No & \multicolumn{1}{|c|}{ Faktor Peluang Perusahaan } \\
\hline 1 & Pangsa Pasar Yang Luas \\
\hline 2 & Perkembangan Pemakai Yang Pesat \\
\hline 3 & Adanya Penawaran Kerjasama Dengan Perusahaan Lain \\
\hline 4 & Munculnya Pusat-Pusat Penjualan baru \\
\hline 5 & Peluang Untuk Melakukan Ekspor \\
\hline
\end{tabular}

Sumber : Hasil Kuesioner PT HM Sampoerna (2018)

\section{Rekapitulasi Faktor Ancaman Eksternal}

Tabel 4. Rekapitulasi Faktor Ancaman Eksternal

\begin{tabular}{|c|l|}
\hline No & \multicolumn{1}{|c|}{ Faktor Ancaman Perusahaan } \\
\hline 1 & Banyaknya Pendatang Baru \\
\hline 2 & Adanya Kemungkinan Perpindahan Sumber Daya Manusia \\
\hline 3 & Situasi Politik Yang tidak Menentu \\
\hline 4 & Adanya Produk Peniru \\
\hline 5 & Keterlambatan Pengiriman Produk Dari Pabrik \\
\hline
\end{tabular}

Sumber : Hasil Kuesioner PT HM Sampoerna (2018)

\section{Hasil Kuesioner Pembobotan Faktor Internal dan Eksternal}

Untuk langkah selanjutnya dalam tahap pengumpulan data, yaitu dengan mengunakan kuesioner pembobotan faktor internal dan faktor eksternal untuk menentukan bobot pada faktor internal dan eksternal.

\section{Tahap I : Tahap Input Data}

Setelah data-data yang dibutuhkan terkumpul, selanjutnya menginput data-data tersebut dalam penentuan bobot dengan perbandingan berpasangan baik untuk faktor internal maupun untuk faktor eksternal. Kemudian hasil-hasil dari tabel penentuan bobot tersebut dinormalisasi agar dapat diperoleh bobot akhir yang akan dipergunakan dalam matriks IFAS dan matriks EFAS.

\subsection{Matriks IFAS (Internal Faktor Analysis Summary)}


Didalam Matrik IFAS ini, data yang diperoleh adalah data yang berasal dari Tabel normalisasi bobot faktor internal dan juga data yang diperoleh dari kuesioner penilaian skor faktor internal perusahaan.

\subsection{Matriks EFAS (External Factor Analysis Summary)}

Didalam matrik EFAS ini, data yang diperoleh adalah data yang berasal dari tabel normalisasi bobot faktor eksternal dan data yang diperoleh dari kuesioner penilaian faktor eksternal perusahaan.

\section{Tahap II : Tahap Pencocokan Data Perusahaan}

Dalam tahap pencocokan ini, digunakan dua metode, yaitu: matriks internal eksternal dan diagram matriks SWOT. Hal ini dilakukan agar diperoleh strategi yang benar-benar tepat untuk dijalankan perusahaan.

\subsection{Hasil Matrik Internal Eksternal (IE)}

Berdasarkan hasil dari tabel Matrik IFAS dan tabel Matrik EFAS (tabel 10), diketahui bahwa nilai IFASnya adalah 2,64854 dan nilai EFASnya adalah 2,32827. dengan demikian PT HM Sampoerna berada pada sel nomor 5, yaitu suatu keadaan dimana perusahaan mengalami suatu masa pertumbuhan. Dengan demikian dapat diketahui strategi yang sebaiknya dijalankan adalah strategi pertumbuhan melalui Integrasi Horisontal.

Strategi pertumbuhan melalui Integrasi Horisontal adalah suatu kegiatan untuk memperluas perusahaan dengan cara membangun di lokasi lain, dan meningkatkan jenis produk serta jasa.

Tujuannya relatif lebih difensif, yaitu menghindari kehilangan penjualan dan kehilangan profit. Perusahaan yang berada di sel ini dapat memperluas pasar, fasilitas produksi, dan teknologi melalui pengembangan internal dan eksternal perusahaan. 


\subsection{Hasil Diagram SWOT}

\section{BERBAGAI PELUANG}

KEKUATAN
INTERNAL

\begin{tabular}{c|c} 
3. MENDUKUNG & 1. MENDUKUNG \\
STRATEGI & STRATEGI AGRESIF \\
TURAROUND & MENDUKUNG \\
STRATEGI DEFENSIF & $\begin{array}{c}\text { MENDUKUNG } \\
\text { STRATEGI } \\
\text { DIVERSIFIKASI }\end{array}$
\end{tabular}

KELEMAHAN

INTERNAL

Sumber : Hasil Kuesioner HM Sampurna, Tbk ( (2018)

Berdasarkan hasil dari tabel matrik IFAS dan tabel Matrik EFAS, diketahui bahwa nilai IFAS $=$ 2,64584 dan nilai EFAS = 2,32827 dan juga berdasarkan perhitungan dari jumlah nilai kekuatan (S) setelah dikali dengan skor lebih besar daripada jumlah nilai kelemahan $(\mathrm{W})$ setelah dikali dengan skor, yang berarti perusahaan mempunyai kekuatan dari segi internalnya. Begitu pula dengan jumlah nilai peluang (O) setelah dikali dengan nilai skor yang lebih besar daripada jumlah nilai ancaman (T) setelah dikali dengan skor, yang berarti perusahaan mempunyai banyak peluang.

Berdasarkan penjelasan tersebut, PT HM Sampoerna berada pada kuadran ke-1 (satu), yaitu suatu keadaan dimana perusahaan memiliki kekuatan dari segi internal dan juga mempunyai banyak peluang PT HM Sampoerna harus menggunakan serta memanfaatkan kekuatan internalnya secara maksimal dan memanfaatkan peluang yang ada. Strategi yang tepat adalah dengan menggunakan kekuatan untuk memanfaatkan peluang jangka panjang yang besar yaitu dengan strategi agresif.

Berdasarkan diagram SWOT maka dapat diketahui bahwa perusahaan sedang menjalankan strategi SO (Strength and Opportunities) yaitu strategi dimana perusahaan menggunakan kekuatan dan peluang yang dimiliki untuk menjalankan usahanya. Dengan demikian perusahaan sebaiknya berkonsentrasi untuk melakukan 
inovasi produk, mempertahankan kualitas produk dan harga yang stabil serta memperluas jaringan pemasaran perusahaan dan memanfaatkan fasilitas perusahaan yang ada dengan baik.

Untuk meningkatkan kualitas produk dan melakukan inovasi produk perusahaan dapat melakukan sebagai berikut (1) Perusahaan harus selalu dapat membuat inovasi terbaru dan juga model yang lebih menarik sehingga membuat konsumen bangga untuk menggunakan produk tersebut (2) Perusahaan harus dapat mengantisipasi perkembangan pasar yang semakin bersaing dengan hadirnya pesaing dan pendatang baru (3) Perusahaan harus berkerja keras agar dapat menjaga kualitas dari produk yang ada untuk memenuhi standar baku perusahaan (5)Perusahaan harus dapat mempertahankan harga jual produknya yang lebih stabil sehingga dapat berpengaruh dengan kehadiran produk-produk lokal yang sejenis.

Untuk memperluas jaringan penjualannya dan memaksimalkan penggunaan fasilitas, PT HM Sampoerna dapat melakukan hal-hal berikut (1) Untuk memperluas jaringan penjualannya perusahaan harus membuka butik-butik dan outlet-outlet di kota-kota lainnya yang dianggap mempunyai pangsa pasar yang besar dan strategis dengan fasilitas pelayanan yang lengkap untuk memperluas penjualannya sehingga produknya dapat dikenal secara luas oleh konsumen (2) Fasilitas yang ada harus lebih ditingkatkan untuk mencapai hasil yang maksimal agar dapat memberikan citra yang baik kepada konsumen, sehingga secara tidak langsung dapat membantu kinerja dari perusahaan (3)Perusahaan harus terus berupaya meningkatkan tenaga pemasaran yang handal dalam melakukan tugasnya untuk menawarkan barang dan mendistribusikannya kepada konsumen, hal itu dapat dilakukan dengan menawarkan produknya kepada toko dan warung yang bergerak dibidang penjualan rokok.

\section{KESIMPULAN}

Berdasarkan hasil penelitian dapat kesimpulan sebagai berikut : 
1.1 Kekuatan (Strenghts) pada PT HM Sampoerna adalah berupa: produk yang memiliki kualitas yang baik, harga produk yang relatif stabil, adanya layanan purna jual, lokasi perusahaan yang strategis, dan adanya brand image yang baik. Sehingga dengan adanya brand image dan harga produk yang relatif stabil serta ditunjang dengan kualitas produk maka akan mempunyai pengaruh yang cukup besar dalam meningkatkan kekuatan perusahaan.

1.2 Peluang (Opportunities) pada PT HM Sampoerna (adalah berupa : pangsa pasar yang luas, perkembangan produk yang pesat, adanya penawaran kerjasama dengan perusahaan lain, munculnya pusat-pusat penjualan baru, dan peluang untuk melakukan ekspor. Berdasarkan peluang-peluang yang ada di atas perusahaan dapat memasarkan produknya lebih luas kepada konsumen.

1.3 Berdasarkan IFAS (Internal Factor Analysis Summary) dan EFAS (External Factor Analysis Summary) diketahui bahwa nilai IFAS nya 2,64584 dan nilai EFAS nya 2,32827. maka strategi yang tepat yang dapat direkomendasikan untuk HM Sampurna, Tbk adalah Integrasi Horisontal yaitu memperluas perusahaan dengan cara membangun butik-butik dan outlet-outlet baru di kota-kota dan daerahdaerah.

1.4 Berdasarkan hasil dari diagram SWOT PT HM Sampoerna berada pada kuadran ke 1, dimana memiliki kekuatan dari segi internal dan mempunyai banyak peluang, sehingga strategi yang tepat adalah dengan mengunakan kekuatan untuk memanfaatkan peluang jangka panjang yang lebih besar yaitu dengan strategi agresif.

1.5 Berdasarkan hasil matrik SWOT dapat diketahui bahwa PT HM Sampoerna sebaiknya mengunakan strategi SO yaitu strategi yang mengunakan kekuatan untuk memanfaatkan peluang. Hasil dari matrik SWOT yang didapat berupa mempertahankan dan meningkatkan kualitas produk dengan brand image yang 
baik serta menambah pusat-pusat penjualan produk yang baru dan memperluas jaringan penjualan melalui ekspor.

\section{Saran}

Adapun saran-saran yang dapat diberikan oleh penulis adalah sebagai beriku $\mathrm{t}$ :

2.1 Strategi yang dapat diterapkan dalam kondisi ini adalah mendukung kebijakan pertumbuhan yang agresif (growth oriented strategy). Ini merupakan situasi yang menguntungkan perusahaan tersebut untuk memilih peluang yang ada dengan melihat kekuatan perusahaan tersebut sehingga peluang dapat dimanfaatkan secara benar dan tepat oleh perusahaan

2.2 Berdasarkan peluang yang ada dari hasil penelitian yang dilakukan penulis, PT HM Sampoerna perlu memperluas pangsa pasarnya ke berbagai daerah yang mempunyai pangsa pasar yang potensial untuk mengembangkan jaringan penjualan serta mengembangkan produk-produknya dalam mengikuti perkembangan selera agar penjualan dapat lebih ditingkatkan

2.3 Karyawan harus dapat meningkatkan loyalitasnya terhadap perusahaan agar perusahaan dapat memaksimalkan hasil kinerja perusahaan tersebut, dan juga perusahaan harus memperhatikan kebutuhan dari karyawan.

2.4 Perusahaan harus terus menjaga hubungan baik yang sudah terjadi dengan member-member yang ada untuk dapat menjaga citra yang baik dimata konsumen.

2.5 Perusahaan harus selalu mengikuti perkembangan selera dan trend yang ada agar produk-produk yang ada tidak ketinggalan jaman, dan perusahaan harus sering mengeluarkan koleksi-koleksi produk terbaru ke pusat penjualan yang ada.

2.6 Perusahaan harus dapat meminimalisir kelemahan-kelemahan yang ada dalam perusahaan agar dapat bersaing di dalam pasar serta harus terus melakukan inovasi-inovasi agar tidak terancam oleh pesaing-pesaing yang lain. 


\section{DAFTAR PUSTAKA}

David, Fred R. (2004). Manajemen Strategis : Konsep. Seventh Edition. PT. Intan Sejati Klaten, Indonesia

Hariadi, Bambang. (2003). Strategi Manajemen. BanyuMedia Publishing, Jakarta.

Hisrich, Robert D. William P Peter. (2000). Entrepreneurship. Fourth Edition. Mc Graw Hill Companies, Singapore.

Madura, Jeff. (2001). PengantarBisnis. Edisi Pertama. Salemba Empat, Jakarta.

Rangkuti, Fredy. (2000). Analisis dan Teknik Membedah Kasus Bisnis. PT. Gramedia Pustaka Utama, Jakarta, Indonesia.

Robinson and Pearce. (2000). Strategic Management: Formulation, Implementation and Control. Seventh Edition. Mc Graw Hill Higher Education, Singapore.

Sugiyono. (2003). Metode Penelitian Bisnis. CV. Alfabeta, Bandung, Indonesia.

Supranto, J. (2003). Statistik Teori dan Aplikasi. Erlangga, Jakarta.

Suryana. (2000). Kewirausahaan. PT. Salemba Empat, Jakarta.

Tjiptono, Fandy. (2001). Strategi Bisnis, Andi Offset, Jakarta.

Triandaru, Sigit. (2001). Ekonomi Mikro: Pendekatan Kontemporer. PT. Salemba Empat, Jakarta.

Tunggal, Amin Widjaja. (2004). Manajemen Strategik. Edisi Pertama. Harvarindo, Jakarta.

Umar, Husein. (2002). Strategic Management In Action. PT. Gramedia Pustaka Utama, Jakarta, Indonesia.

Umar, Husein. (2003). Riset Pemasaran dan Prilaku Konsumen. Cetakan Ketiga. PT. SUN, Jakarta. 